\title{
Geographical Indications Protection: Collective Action for Local Empowerment and Wealth Creation
}

\author{
Dr. RANTI FAUZA MAYANA, SH \\ Law Faculty of Padjadjaran University \\ Email: ranti_fauza@yahoo.com
}

TISNI SANTIKA, SH, MH

Law Faculty of Pasundan University

Email: tisnisantika@yahoo.co.id

\begin{abstract}
Geographical Indications is a sign used on goods from a specific geographical origin and possess qualities or a reputation that are resulting and strongly connected to that place of origin. Geographical Indications provides huge possibility for value added to the natural richness of a country and to the skills, innovation and creativity of local population and also gives local products a distinguishable identity (Addor \& Grazioli, 2002). This distinguishable identity is considered as a determinant factor in global market. According to a Consumer Survey performed in European Union, $40 \%$ of the consumers are ready to pay $10 \%$ of the premium for origin guaranteed products (European Commission, 2004) that's why Geographical Indications should be protected in order to prevent the misleading information of the true origin of the products as well as protecting the rights of the producers. Geographical Indications always strongly linked with origin territorial and local community, this fact put Geographical Indications in a rooted and strategic position for local society socio-economic upgrading. This paper aims to identify the strengthening of Geographical Indications as one of the most potential tools in escalating the local empowerment, branding of local product and wealth creation of a nation. In terms of legal theory this paper engages with literature upon geographical indication, legal protection and sustainable development mainly based on Elinor Ostrom's "Theory of Collective Action" in initiating the local empowerment, enhancing nation wealth creation and governing the overflowing of GI products in global scale. This paper provides an analysis of what legal frameworks should be adopted to progressively implement Geographical Indication which range from international law and covenants to national legal instrument, government action and local community participation.
\end{abstract}

Keywords: Geographical Indications, Legal Protection, Collective Action, Local Empowerment, Wealth Creation.

\section{Introduction}

The fact that the world population is inevitably increased caused a great concern of the sustainable supply of food, agricultural products, medicines and others daily products. (Report from the Commission to the European Parliament, 2013). The supply of those products are highly depend on natural richness and local skill in creating beneficial products and nearly all of valuable Geographical Indications related to agricultural products, have qualities that derive from their place of production and are influenced by specific local factors, such as climate and soil quality as the result the certain characteristic and quality of these products commonly linked with its geographical origin. This is the fundamental concept behind 
Geographical Indications: Specific geographical regions yield certain product characteristics and qualities that cannot be replicated precisely elsewhere (Raustiala and Munzer, 2007), in other words the geographical factor is essential determinant factors of product quality.

As local as Geographical Indications rooted, it currently stands in the intersection between the two international affairs: global trade competition and intellectual property. This is because the obvious and massive advantages of Geographical Indications both as global competitive factors and intellectual property. Geographical Indications designed to reward goodwill and reputations created, built, maintained and preserved by producer over years or even among generations in maintaining a traditionally high standard of quality combine with innovation and improvement (Downes \& Laird, 1999).

The economic viability of Geographical Indications products is compelling. In France there are more than 600 registered GI products with estimated 142.000 producers and resulting 19 billions of Euro as annual gain. (Lalague, 2007). The worldwide sales value of Geographical Indications products registered in the European Union was estimated at $€ 54.3$ billion in 2010 at wholesale stage in the region of production; it increased by $12 \%$ between 2005 and 2010 . Wines accounted for $56 \%$ of total sales ( $€ 30.4$ billion), agricultural products and foodstuffs for $29 \%$ ( $€ 15.8$ billion) (European Commission, 2012), another example is Florida Orange, although oranges did not originate in Florida, but for the last 500 years they have grown there and became one of the most expansive industry because the distinctive resulted from the soil, climate and process of production. Florida Orange have become a major supply worldwide and generated USD 9 Million income and created national 80.000 jobs and expanded 230,7 acres of land utilizations. (Herzeg, Rund and Lee, 2013).

Considering the strong linkage between Geographical Indications with the identity of a nation supporting by massive possibility of Geographical Indications products in wealth creation through community empowerment in producing local products with global scale of competitive edge the two most important statements of the problems in this paper are:

1. How to adopt a suitable legal framework of Geographical Indications to enhance local empowerment and nation wealth creation.

2. How to escalate the role of Geographical Indications to protect local product in global price-based economic competition.

\section{Objectives}

This paper aims to identify two problem statements:

1. To analyze suitable legal framework to adopt for Geographical Indications to enhance local empowerment and nation wealth creation.

2. To identify the role of Geographical Indications to protect local products in global price-based economic competition.

\section{Significance of the Study}

This research expected to be the reference for interested parties and institutions related to the legal framework formulation for Geographical Indications protection and implementation in Indonesia, the Indonesian's local creativity products with Geographical Indications potential and the possibility to enhance the role of Geographical Indications for local community empowerment in wealth creation effort of a nation and further in the scope of creating value added and competitive edge for local product in global price-based economic competition. This paper also aims to identify the challenges in explore maximum potentials of Geographical Indications products and to find the solution in socio legal approach. 


\section{Theoritical Studies}

\section{Geographical Indications Overview}

Geographical Indications in a product mainly use to emphasize three vital aspects of product identity / branding: the origin of products, the quality, special characteristics and reputation of product, the influence of geographic and human factor of product origin to its quality and character (Nansa, 2013). Geographical Indications has a very potential industrial scale development since Geographical Indications is categorized as industrial property according to Paris Convention for the Protection of Industrial Property. Article 10 of Paris Convention clearly prohibits direct or indirect use of a false indication of the source of the goods or the identity of the producer, manufacturer or merchant (Lahdesmaki, 2007). Paris convention also accommodate the community ownership of Geographical Indications as industrial property by stating the interested party as the rights subject, where interested party defines widely as any producer, manufacturer or merchant, whether a natural person or a legal entity, engaged in the production or manufacture of or trade in such goods and established either in the locally falsely indicated as the source or in the region where such locally is situated, or in the country falsely indicated, or in the country where the false indication of source is used, shall in any case be deemed an interested party.

TRIPs Agreement defines Geographical Indication as an expression that identifies a product as originating in a particular region where a given quality, reputation, or other characteristic of the good is essentially attributable to its place of origin; in short Geographical Indications apply to a specific region within a given state usually based on climate, geography condition or natural features combines with human factor, such as specific manufacturing skills and traditional innovation (O'Connor, 2004). Although it mentioned that Geographical Indications address with "specific region", in some cases this "specific region" scope can be entire country even though the name enacted to the products may not even the name of a region or a country. For example in 2005 the European Court of Justice stated that Greece had the exclusive right to name its white cheese made of sheep's milk or mixture from sheep's and goat's milk as "Feta" (Justin Huges, 2006), and not just any cheese made in Greece can be called "Feta" although in fact "Feta" is not the name of the place or region in Greece, "Feta" is the Greek word translatable as "slice". The stressing point is that Geographical Indications products must have uniqueness strongly influenced by certain place or region, or as European Commission defined as "le goüt du terroir" or "taste of the earth" as following: (Trubek, 2008)

A distinct, identifiable taste reminiscent of a place, region or locality, foods and beverages that have signature qualities that link their taste to a specific soil with particular climate conditions. Only the land, climate and expertise of the local people can produce the products that live up to its name.

Geographical Indications also can be obtained with the influence human factors found in the product's place of origin, such as specific manufacturing skills and traditional knowledge, for this very reason Geographical Indications identify a certain goods as originating from a particular place and due to the place of origin, consumers are associated the product with a particular quality, specific standards, unique characteristic and well known reputation.

Although Geographical Indications consider as one of industrial property according to Paris Convention and TRIPs Agreement, in fact Geographical Indications being linked closer to traditional knowledge and unfortunately both are still trapped in the crossroad of argumentation regarding to the urgency of intellectual property protection, in the case of Geographical Indications, some argues that it does not cover human innovation or invention and novelty like any other intellectual property rights (De Silva, 2015) while in the fact, the reputation of Geographical Indications is the result of efforts undertaken by local producers in particular region. (WIPO, 2004) 


\section{Geographical Indications in Indonesia: Justification of Legal Protection and Local Empowerment}

Indonesia is one of the biggest archipelagic country consists of 17.508 islands with rich and various land condition, texture and climate mixed with endless traditional knowledge and local wisdom and as consequence many regions are capable of producing high quality, unique, distinctive and characterized products due to its natural, geographical, social and cultural factors. Despite the fact of natural and cultural richness, Indonesia is still struggling to develop a creative economy platform in order to reap a fruitful benefit. (Fadilah H. Arief, 2016)

Indonesia regulates Geographical Indications protection in Law Number 20 year 2016 on Trademarks and Geographical Indications. This law affirms Geographical Indications shall be protected as a sign which indicates the place of origin of goods, which due to its geographical environment factors, including the nature factor, the people / community or the combination of both factor give the specific and unique characteristic and quality on obtained products.

One of the most unique and distinctive signature products of Geographical Indications products in Indonesia is "Luwak Coffee". This coffee produced with the "help" of a civet cat native animal called Luwak. Luwak mostly found in South East Asia Region particularly in Sumatra and Java islands. They move at night, creep along the limbs of coffee bush, sniffing out the sweet red coffee cherries and selecting only the tastiest, after chewing off the fruity exterior, they swallow the hard innards. In the Luwak's stomachs, enzymes in the gastric juices massage the beans. Since the animals belong to carnivore, they only need the coffee mucilage mainly to obtain sugar, fiber and vitamins. After the digestion process, the human then separate the coffee beans from the feces, wash them then put them under the sun until they get dry. After the beans are dry enough they remove the outer skin parchment easily. Raw Luwak coffee loses much weight during the long stages of processes. 10 kilograms of raw luwak coffee will not yield more than 2 kilograms of roasted luwak coffee beans.

Table 1 : Specialty products from Indonesia Marked with GIs (Mawardi, 2009)

\begin{tabular}{|c|c|c|c|c|c|}
\hline \multirow[t]{2}{*}{ No } & \multirow{2}{*}{ Variety } & \multirow{2}{*}{$\begin{array}{l}\text { Name of } \\
\text { Product }\end{array}$} & \multirow{2}{*}{$\begin{array}{c}\text { Specific } \\
\text { Characteristic }\end{array}$} & \multicolumn{2}{|c|}{ Geographical Origin } \\
\hline & & & & Natural Factors & Ethnic \\
\hline 1. & $\begin{array}{l}\text { Coffee } \\
\text { Arabica }\end{array}$ & Kintam & $\begin{array}{l}\text { Medium body, rich } \\
\text { aroma and flavor, } \\
\text { lemony taste }\end{array}$ & $\begin{array}{c}\text { Kintamani } \\
\text { highland at } \\
\text { Southern Slope of } \\
\text { Penulisan and } \\
\text { Batur mountains } \\
\text { Bali, low rainfall }\end{array}$ & Balineese \\
\hline 2 & Furniture & Jepara Carving Furniture & $\begin{array}{l}\text { Complicated pattern, } \\
\text { high craftsmanship, } \\
\text { fully handmade with } \\
\text { high durability, } \\
\text { elegance, stability } \\
\text { and low maintenance, } \\
\text { a honey blonde color } \\
\text { and after one or two } \\
\text { seasons outdoors it } \\
\text { will turn soft, silver } \\
\text { gray and stays like } \\
\text { that forever without } \\
\text { ever warping, }\end{array}$ & $\begin{array}{l}\text { Smooth to the } \\
\text { touch yet strong } \\
\text { Indonesian teak } \\
\text { grows in dry, } \\
\text { hilly terrains of } \\
\text { forest, cannot } \\
\text { grow in } \\
\text { rainforest, from } \\
\text { planting, growing } \\
\text { until be a good } \\
\text { teak hardwood } \\
\text { will takes at least } \\
50 \text { years }\end{array}$ & Javaneese \\
\hline
\end{tabular}




\begin{tabular}{|c|c|c|c|c|c|}
\hline & & & $\begin{array}{l}\text { twisting, rotting or } \\
\text { splintering }\end{array}$ & & \\
\hline 3 & Pepper & Muntok White Pepper & $\begin{array}{l}\text { Pepper with musky, } \\
\text { warm and creamy } \\
\text { flavor resulting from } \\
\text { processing methods } \\
\text { such as fermentation } \\
\text { involves soaking the } \\
\text { pepper in water in } \\
\text { order to obtain the } \\
\text { fine white kernels }\end{array}$ & $\begin{array}{l}\text { Bangka and } \\
\text { Belitung Soil } \\
\text { type : reddish } \\
\text { brown and sandy } \\
\text { soil, significant } \\
\text { rainfall and }\end{array}$ & $\begin{array}{c}\text { Various } \\
\text { Bangka } \\
\text { ethnic : } \\
\text { Indonesia, } \\
\text { Malaysia } \\
\text { and Chinese }\end{array}$ \\
\hline 4 & $\begin{array}{l}\text { Coffee } \\
\text { Arabica }\end{array}$ & $\begin{array}{l}\text { Gayo Mountain Coffee } \\
\text { JPW Coffee } \\
\text { Acecialtycoffec.coid } \\
\text { Aayole }\end{array}$ & $\begin{array}{l}\text { Medium acidity, } \\
\text { medium body, rich } \\
\text { aroma and flavor }\end{array}$ & $\begin{array}{l}\text { Gayo highland } \\
\text { (Slope area of } \\
\text { five mountains of } \\
\text { Peutsago, } \\
\text { Bateekeubelie, } \\
\text { Geureundong, } \\
\text { Leuser and } \\
\text { Abongabong }\end{array}$ & Gayoneese \\
\hline 5 & Rice & 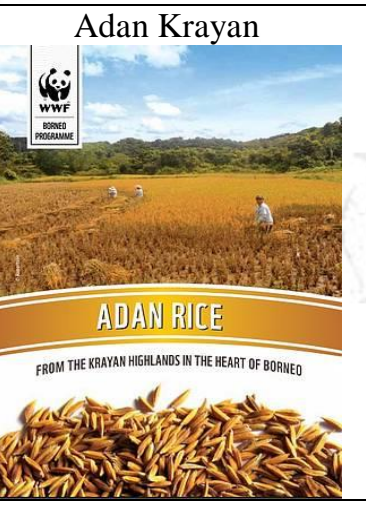 & $\begin{array}{l}\text { Small grain and fine } \\
\text { texture and pleasant } \\
\text { taste. }\end{array}$ & $\begin{array}{l}\text { Krayan and South } \\
\text { Krayan } \\
\text { subdistricts, } \\
\text { Nunukan } \\
\text { regency, in the } \\
\text { province of North } \\
\text { Kalimantan with } \\
\text { altitude of } 1000 \\
\text { m above sea level }\end{array}$ & $\begin{array}{l}\text { Ludayeh } \\
\text { and Sa'ban } \\
\text { ethnic } \\
\text { groups }\end{array}$ \\
\hline 6 & $\begin{array}{l}\text { Arabica } \\
\text { Coffee }\end{array}$ & Toraja Coffee & $\begin{array}{l}\text { Balance between } \\
\text { acidity and bitterness, } \\
\text { rich aroma and flavor }\end{array}$ & $\begin{array}{l}\text { Tana Toraja } \\
\text { highland, Quarles } \\
\text { mountainous } \\
\text { area, South } \\
\text { Sulawesi, } \\
\text { Medium rainfall }\end{array}$ & Torajaneese \\
\hline 7 & $\begin{array}{c}\text { Sweet } \\
\text { Potato / } \\
\text { Cassava }\end{array}$ & 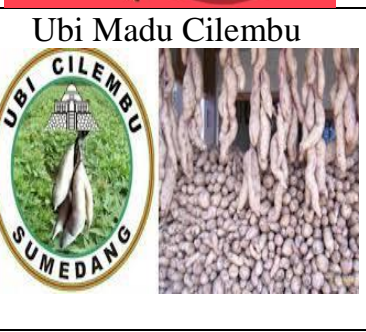 & $\begin{array}{l}\text { Sticky sweet honey } \\
\text { taste, when heated in } \\
\text { the oven will produce } \\
\text { more sticky sweet } \\
\text { honey thick liquid, } \\
\text { yellow-reddish color } \\
\text { with } 7100 \text { IU of } \\
\text { Vitamin A }\end{array}$ & $\begin{array}{l}\text { Cilembu Village, } \\
\text { Pamulihan, } \\
\text { Sumedang, } \\
\text { Planted in } \\
\text { Kareumbi } \\
\text { Mountain Hills }\end{array}$ & Sundaneese \\
\hline
\end{tabular}


Despite the fact that Indonesia has already had considerably complete legal bases with its active participation as state party in related conventions like Paris Convention, Berne Convention or member state in relevant organizations for example WTO - TRIPs Agreements and WIPO, the intellectual property regime provide by those conventions and organizations to protect Geographical Indications haven't properly enacted in practical platform due to the lack of legal instruments and community awareness caused huge moral and financial loss by unjust enjoyment and enrichments, misappropriation and misleading use of place of origin mostly by foreigners (Miranda Risang Ayu Palar, 2010), this bitter fact set up a high urgency in formulating the comprehensive legal instrument, initiate government action and community participation to pursue the utility of Geographical Indications protection in supporting economic development. According to Economic Growth Stimulus Theory, a comprehensive intellectual property protection with an effective and systematic legal rules support by its implementing regulation is important tool of economic development itself. (Ranti Fauza Mayana, 2004).

\section{Geographical Indications Protection for Local Products in Global Price-Based Economic Competition}

Geographical Indications stands as public domain and will remain so because it's strongly connected to nature and culture, and nature and culture belong to the people. (Mezey, 2007) but there are huge possibilities for people to take or use something in the public domain and turn it into private property (Hyde, 2010) and further gain monopolistic use that in many cases breaches the rights of local communities as original custodian and authentic manufacturer.

Geographical Indications has been a well known concept by the consumers in the old Europe and implemented in many countries with massively positive impact from the preservation of traditional knowledge, regional branding, the local synergies with the economic sectors are enhance the products attractiveness in the eyes of consumer. Geographical Indications is intellectual property protection for a product differ from copyrights patents and trademark. Geographical Indications do not only required novelty and distinctiveness, it emphasizes strongly on historical dimension, reputation and particular links between the product and its geographical area as the important grounds for the protection. (ThevenodMottet, 2007), the qualities or reputation of the product should be essentially due to the place of origin.(WIPO, 2004).

Geographical Indications also play an important role in value creation of products. The analysis reflected that Geographical Indications products have better market positioning compared to non Geographical Indications products with 2.23 value premium rate, means that Geographical Indications products were sold 2.23 times higher than Non Geographical Indications products in the same quality (Chever, 2012).

\section{Methodology}

This research is preceded by studying and examining the literature on theories and concept related to the theme discussed. The method is qualitative research characterized by its aims, which relate to understanding some aspect of social life in exploring the what kind of legal platform to adopt in protecting Geographical Indications as value added for distinctive authentic local products of Indonesia.

Qualitative methods are also expected to be effective tool in identifying the problems in intangible forms, community collective action, socioeconomic phenomena, cultural value and the society's awareness of the value of their region territory potencies and traditional knowledge and methods in producing and manufacturing high quality products. This qualitative research also expected to be able to identify what kind of legal platform to adopt as appropriate and internationally accepted legal regulation for Geographical Indication protection and provide recommendations for the better system as the conclusions. 


\section{Result of Analysis}

\section{The Implementation of Geographical Indications on Local Empowerment and Wealth Creation}

Geographical Indications are very important for a nation because they provide livelihood and opportunities for people in mostly poor and remote areas, strong Geographical Indications protection help the farmers to get a good income and functioned as generator of jobs and wealth creation for local surrounding. For example Sri Lanka : Export of Ceylon Tea generate an annual income of US \$ 1,5 billion and this revenue covers the hard currency requirement necessary for the entire food import bill of the country. With $2 \%$ contribution to the Nation's GDP and dependence of $10 \%$ of the population on the industry, Ceylon tea plays a pivotal role in the economy of Sri Lanka (De Alwis, 2013).

In European Union the estimate sale value of GI products in 2010 was $€ 54.3$ Billions, $56 \%$ of values are for wines, $29 \%$ for agricultural products and foodstuffs. This sales values are increase by $12 \%$ from 2005 to 2010 and the agricultural and food sector are $19 \%$ increased, the greatest increase of the period (European Commission, 2012).

The registration and Geographical Indications granting are merely not a productive protection for those products, it required a strong and solid actions from the interested parties to formulate the legal protection into a comprehensive platform with socioeconomic benefits by conducting these several stages in developing a comprehensive Geographical Indications protection:

1. The identification and database creation. This early stage consists of the inventorying national Geographical Indications products by defining the unique taste and distinctive characteristic of the products from each region.

2. Certification of Origin, in this stage the interested parties mainly the local producer of Geographical Indications products and the local government set the agreed standard, characteristic and certain qualities of Geographical Indications products, assessing whether the products have potentials in local or global markets and grant Geographical Indications Certification

3. The empowerment of local community of origin through training, equipment and financial aid, product quality improvement by introducing new processing method, product packaging and product upgrading (Misnawi and Gerz, 2007) and setting up the mechanism to determine the right to use the Geographical Indications to any producer and manufacturer of Geographical Indications products and established boundaries according to mutually agreed terms.

4. Identification of interests. This stage focused on the identification of the interest of each participant in Geographical Indications products market chain. For example the interest of country / place of origin to be acknowledged and forming a nation branding through the product identity's name, the local community and the producers of the product to be protected by proper legal instruments, other market actors to be able to get the original products with preserved quality and for the consumer to get the accurate information regarding product origin. This is also the stage to make the deal and guideline about the interests and the role of each participant.

5. Widening the market scope of the Geographical Indications products by implementing certain marketing strategy, build partnership with other market chain actors for example by initiating a dialogue and cooperation with producers, exporters and business association.

6. The Monitoring Stage. This is the last and continuous stage to be performed. The country / place of origin took the responsibility as the facilitator as well as the examiner responsible for supervise the whole process and ensure that all participants conduct each roles according to the guidelines by establishing a control scheme provides traceability, verification in order to ensure the particular quality of Geographical Indications products and the use of Geographical Indications are compliance with regulations. 
The stages strongly need a collective action since Geographical Indications consider as community ownership and used primarily for society upgrading, local empowerment and nation wealth creation. Collective action is not merely about working with a group of people, but more about collaboration, working in a group that generates "collective knowledge" in a more effective and efficient way to accomplish better and beneficial results for all (Kramsch, 1998). The effective and comprehensive implementation of Geographical Indications prove that in the field of intellectual property, private ownership or monopoly rights is not the only instrument to protect resources from ruin or degradation and in many places in the world, communities develop ways to govern the commons to protect common property to ensure the preservation for their daily needs and conduct sustainable development for future generations. In accordance with the "Collective Action Theory" by Elinor Ostrom there are 8 basic principles for managing a common and their property to enact Geographical Indications progressively in local empowerment and wealth creation as follows: (Ostrom, 1998).

1. Define clear group boundaries. Group boundaries are important to determine the interested parties and beneficiaries of Geographical Indications and also as a mean of protection that enables those who have the right to defend against misappropriation, misuse and any use without permission (free-riders).

2. Match rules governing use of common goods to local needs and condition. Since Geographical Indications has undeniably links with region and community, it's important for the rules to be practical and accepted as living law in the society.

3. Ensure that those affected by the rules can participate in governing and modifying the rules. The interested parties should be able to initiate the needed changes of the rules in order to create an ideal environment; government action should be complement with community participation.

4. Make sure the rule - making rights of community members are respected by outside authorities. Community should be seen as a legal concept, because each community has its own regulatory problem, requirements and needs, the rights of community should be acknowledged and respected. (Cotterrell, 2011).

5. Develop a system, this system carried out by community members for monitoring member's behavior in collective action scheme.

6. Use graduated sanctions for rule violators, when certain function is not performed, it means that the related subjects are liable to sanction. Sanction is the last resort to ensure the sustainability of the system. Cooperation can be sustained when non - cooperators are punished and cooperators are rewarded. (Van Lange, Rockenbach, Yamagishi, 2014).

7. Provide accessible, low cost means for dispute resolution. This dispute resolution should be based on public interest and harmless to the society.

8. Build responsibility. This responsibilities are set for governing the common resource in nested tiers from the lowest level up to the entire interconnected system of collective action.

The Escalation of Geographical Indications Protection for Local Products in Global Price Based Economic Competition

The consumer's behavior in global market showing a huge tendency of increasing willingness to pay extra amount of price for original products with specific characteristics present in the products they buy linked with origin - bound characteristic of a product (WIPO, 2004). According to a Consumer Survey performed in European Union, $40 \%$ of the consumers are ready to pay $10 \%$ of the premium for origin guaranteed products (European Commission, 2003). Geographical Indications also strongly connected with local food security, for example in European Union sales value of Geographical Indications products by destination in 2010 are dominated by domestic market (60,1\%: $€ 32,662$ billions) (AND - International Survey for DG-AGRI). In 2010,the total sales value of agricultural products and foodstuffs under Geographical Indications was $€ 15.8$ billion with cheeses, meat products and wine as the main sectors. (European Commission, 2003). 
This tendency emphasizing how successfully Geographical Indications protection has been used in many jurisdictions therefore escalation of Geographical Indications protection as determinant factor in global trading offer a possibility of massive significant results. Geographical Indications considered as a very strong brand with inevitable uniqueness completes with preserved exclusivity. Geographical Indications has globally accepted and acknowledged, and in global trade, brand recognition is an essential aspect of marketing. Geographical Indications can be the major driver in developing brands as the products differentiators and quality linked to origin place and local characteristic and contributes to rural development, local employment creation, generators of jobs and wealth creation.

Sustainable development of Geographical Indications products required a collective action supported by three interrelated dimensions: (Busumtwi-Sam, 2009).

1. The Normative Dimension: The sets of rules, norms, principles that that clearly define the appropriate and inappropriate conducts.

2. The Cognitive Dimension: The understanding of each participant's role considering the linkage between environment and development as the basic design in determining what kind of actions or conducts that might be need or should be perform by each actors.

3. The Regulative Dimension: The fully structured and settings / platform where each participants are collaborating and cooperating in activities to achieve common interest of sustainable development.

In this potential era of urban markets, the demand for quality for processed food and other biodiversity based products with Geographical Indications are growing simultaneously with health, environmental, social concerns and sustainable development as influent factors for consumer's buying decision (Thomann, Devaux, Ordinola, Cuentas,Urday, Sevilla and Andrade-Piedra, 2009). The potential source and technological capability share the same important impact in creating sustainable, good quality and economically viable Geographical Indications products, this put cooperation and collective action as the most effective stakeholder platforms as a space for interaction with multipurpose from reducing conflict, building trust, generate greater trust and partnership leads to joint action and collective action in creating the Participatory Market Chain Approach (Bernet, Thiele and Zschocke, 2006) as the tool to identify and explore new business opportunities to achieve common interest, further collaboration and innovation.

Beside the wide scope of possibilities, Geographical Indications products marketing in global market also has its own potential challenges, for example the uneven distribution of benefit between countries and the unequal position among participants in formulating the common rules, since the rules mostly set by participants who have huge capital and big economic power based their own term and requirements. (Bhatia, 2013). These challenges require the policymaker to create functional Global Value Chain formulation and integrate Global Value Chain into the national development of Geographical Indication policy and strategy in developing countries as well as harmonizing the formulation with global economy.

Global Value Chain in Geographical Indications products has enormous possibility of simultaneous and sustainable benefit for all market chain actors (Riyadi, 2008). Geographical Indications protection able to enhance the additional value of goods, as branding and marketing strategy, facilitating commercial exploration for local products and provide protection from counterfeit infringement, for the benefit of manufacturer and producer and in the same time once the Geographical Indications standards are set, the quality and standard of the products is maintained as guarantee for the consumer to ensure the quality of goods meet the consumer's expectation.

Besides the trade-related impact, Geographical Indications also support socio economic development as inevitable impact from widening the employment field, develop the agro tourism and eco tourism to strengthen regional economy and public welfare. This commercial exploration of Geographical Indications products also consider as eco friendly, maintain and preserve the nature and biodiversity of the region since the conceptual core of Geographical Indications is protection and recognition grant to the products for its 
authenticity, quality and region of origin linkage. Geographical Indications purpose to help individuals, producers, manufacturer or groups of community identify, protect and gain fruitful results and benefits Geographical Indications production (Donaldson, 2002). Geographical Indications also can be the tool to preserve traditional knowledge (TK) and Traditional Cultural Expression since in certain region since particular products like handicrafts and woven are made using natural resources combined with traditional knowledge and traditional cultural expressions. While Geographical Indications are in the public domain according to Intellectual Property regime and do not privately protect the subject, studies show that the socio economic and cultural impact of Geographical Indications protection of particular region bring positive impact as generator of jobs and income creation, limitation the rural exodus (Bowen, 2007), society upgrading and maintain positive environment.

\section{Conclusion}

The conceptual core of Geographical Indication is protection / status grant to the products for its authenticity, quality and heritage, Geographical Indications protection means that producers outside a designated region are not allowed to use recognized Geographical Indications even though they might produce similar products. The most effective legal protection platform to protect Geographical Indications is through government action and community participation. Geographical Indications simultaneously carried few functions: exclusive rights for particular region in the form of intellectual property, the distinctive and attribute of origin for the products, part of nation branding because the distinguishable identity of Geographical Indications products is considered as a determinant factor in global market. Collective action through Global Value Chain are expected to pull out Geographical Indications products to the surface, upgrade the economic viability by creating global markets out of previously discrete and undervalued local markets, Intellectual property protection regime according to TRIPs Agreement appear to be the media to collaborate the New World Technique and Technology with The Old World terroir region for public welfare.

\section{References}

Addor, Felix, Grazioli, Alexandra, (2002), Geographical Indications Beyond Wines and Spirits: A Roadmap for a Better Protection for Geographical Indications in The WTO TRIPs Agreement, The Journal of World Intellectual Property Vol.5 PP.865-897.

Bernet,T., G. Thiele \& T. Zschocke, 2006, Participatory Market Chain Approach (PMCA) User Guide. Lima:International Potato Center (CIP- Papa Andina, http://cipotato.org/wpcontent/uploads/2014/09/003296.pdf.

Bhatia, Ujal Singh,2013. "The Globalization of Supply Chains -Policy Challenges For Developing Countries, World Trade Organization Publication : Global Value Chain in a Changing World, Geneva, https://www.wto.org/english/res_e/booksp_e/aid4tradeglobalvalue13_e.pdf.

Bowen, Sarah, (2007), Re- Locating Embeddedness, A Critical Analysis of the Comté Supply Chain, North Carolina State University.

Busumtwi - Sam, James, 2009, International Cooperation In Sustainable Development, Regional Sustainable Deveopment Review: Canada and USA Vol. I, Encyclopedia of Life Support Systems.

Chever, Tanguy, (2012), Value of Production of Agricultural Products and Foodstuffs, Wine, Aromatised Wines and Spirits Protected by a Geographical Indication (GI), Agriculture Nutrition Development, European Commission.

Cotterrell, Roger, (2011), Community as a Legal Concept? Some Uses of a Law and Community Approach in Legal Theory, Queen Mary School of Law Legal Studies Research Paper No.95/2011.

De Silva, Lihini M, (2015), Geographical Indications - Need of a Registration System for Srilanka, Proceedings of $8^{\text {th }}$ International Research Conference, General Sir John Kotelawala Defence University Publishing, http://www.kdu.ac.lk/proceedings/irc2015/2015/law-009.pdf.

Donaldson, Fred (2002), Jihad vs. McWorld: How Globalism and Tribalism are Reshaping the World by Benjamin R. Barber,Sigma: Journal of Political and International Studies: Vol. 20, Article 7. 
Downes, D.R. Laird, S.A, (1999), Innovative Mechanism For Sharing Benefits of Biodiversity and Related Knowledge: Case Studies on Geographical Indications and Trade Marks, Paper Prepared for UNCTAD Bio Trade Initiative, http://www.ciel.org/Publications/InnovativeMechanism.pdf.

European Commission, (2012). Value of Production of Agricultural Products and Foodstuffs, Wines, Aromatized Wines and Spirits Protected by a Geographical Indication (GI), Final Reports, http://ec.europa.eu/agriculture/sites/agriculture/files/external-studies/2012/value-gi/final-report_en.pdf.

European Union Background Note (2004). Why do geographical indications matter to us?, http://www.southcentre.org.

Fadilah H. Arief, (2016), “Indonesian Crafts : The Overlooked Potential for Geographical Indication”, International Journal of Culture and History, Vol.2 No.3.

Justin Hughes, (2006), Champagne, Feta, and Bourbon: The Spirited Debate about Geographical Indications, University of California, Hastings Law Journal.

Kramsch, Claire, 1998, Language and Culture, Oxford University Press, Oxford.

Lahdesmaki, Paivi, (2007), The Protection of Geographical Indications At The International Level, International Training Modul of Geographical Indications: A Way Forward for Local Development, Agridea Developing Agriculture And Rural Areas, Lausanne, Switzerland.

Lalague, Lionel, (2007), Geographical Indications (GIs) : The Situation in France, International Training Modul of Geographical Indications: A Way Forward for Local Development, Agridea Developing Agriculture And Rural Areas, Lausanne, Switzerland.

Mawardi, Surip, (2009), Establishment of Geographical Indication Protection System in Indonesia, Case In Coffee, WIPO Worldwide Symposium on Geographical Indications Jointly Orgazed by The World Intellectual Property Organization (WIPO) and The Patent of The Republic of Bulgaria.

Mezey, Naomi, (2007), The Paradoxes of Cultural Property, Columbia Law Review, 2004-2046, http://scholarship.law.georgetown.edu/cgi/viewcontent.cgi ?article=1902\&context=facpub.

Misnawi and Gerz, Strid, (2007), Indonesia: Initiative on Geographical Indications in Indonesia, International Training Modul of Geographical Indications: A Way Forward for Local Development, Agridea Developing Agriculture And Rural Areas, Lausanne, Switzerland.

Miranda Risang Ayu Palar, (2010), WIPO Indigenous Panel on The Role of The Public Domain Concept: Experiences in The Fields of Genetic Resources, Traditional Knowledge and Traditional Cultural Expressions: Experiences From Indonesia, WIPO Intergovernmental Committee on Intellectual Property and Genetic Resources Traditional Knowledge and Folklore, Geneva, www.wipo.int/edocs

Nansa, Almusawir, (2013), Legal Instrument for Protection of Geographical Indication Product in Indonesia, Journal of Humanity $\quad$ Volume 1 No.1, www.journalofhumanity.org/index.php/jh/article/view/3/3.

O' Connor, Bernard, (2004), The Law of Geographic Indications, Cameron May International Law and Policy.

Ostrom, Elinor, (1998), A Behavioral Approach to the Rational Choice Theory of Collective Action, American Political Science Association $\quad$ Volume $92 \quad$ No.1 https://wwz.unibas.ch/fileadmin/wwz/redaktion/wipo/Vorlesungen/2012/PolEcon/Ostrom98.pdf.

Ranti Fauza Mayana, (2004), Perlindungan Desain Industri di Indonesia Dalam Era Perdagangan Bebas, Jakarta, PT. Gramedia Widiasarana Indonesia, Jakarta.

Raustiala, Kal, Munzer, Stephen R, (2007), The Global Struggle Over Geographic Indications, The European Journal of International Law Vol.18 No.2.

Report from the Commission to the European Parliament, the Council and the European Economic and Social Committee, (2013), Agricultural Genetic Resources - From Conservation to Sustainable Use, European Commission, Brussels, 28.11.2013 COM (2013) 838 Final.

Riyaldi, (2008), Perlindungan Indikasi Geografis, Manfaat dan Tantangannya, Media HKI Vol V/No.04, Departemen Hukum dan HAM RI, Direktorat Jenderal Hak Kekayaan Intelektual, Jakarta.

Thevenod-Mottet, Erik,(2007), Stakes and Questions Related To The Protection of Geographical Indications, International Training Modul of Geographical Indications: A Way Forward for Local Development, Agridea Developing Agriculture And Rural Areas, Lausanne, Switzerland. 
Thomann, Alice., Devaux, Andre., Ordinola, Miguel., Cuentas, Martha., Urday, Pedro., Sevilla, Mario, Andrade-Piedra, Jorge. 2009, "Native Potato Market Chain and Poverty Reduction: Innovation around Corporate Social Responsibility”, Presented at the $15^{\text {th }}$ Triennial International Society of Root Crops, http://www.istrc.org/images/Documents/Symposiums/Fifthteenth/s11_thomann.pdf.

Trubek, Amy B, (2008), The Taste of Place: A Cultural Journey Into Terroir, University of California Press, Berkeley and Los Angeles, California.

Van Lange, Paul AM., Rockenbach, Bettina., Yamagishi, Toshio., (2014), Reward and Punishment in Social Dilemmas, Oxford Scholarship Online, http://www.oxfordscholarship.com/view/10.1093/acprof:oso/9780199300730.001.0001/acprof9780199300730.

World Intellectual Property Organization, (2004), Geographical Indications: An Introduction, WIPO Intellectual Property Handbook, WIPO Publication No.489 (E).

World Intellectual Property Organization, (2004), Developing a Geographical Indication - Why?, WIPO Intellectual Property Handbook, WIPO Publication No.489 (E).

World Intellectual Property Organization, (2004), Protecting Geographical Indications - a Step in Developing a Geographical Indications, WIPO Intellectual Property Handbook, WIPO Publication No.489 (E).

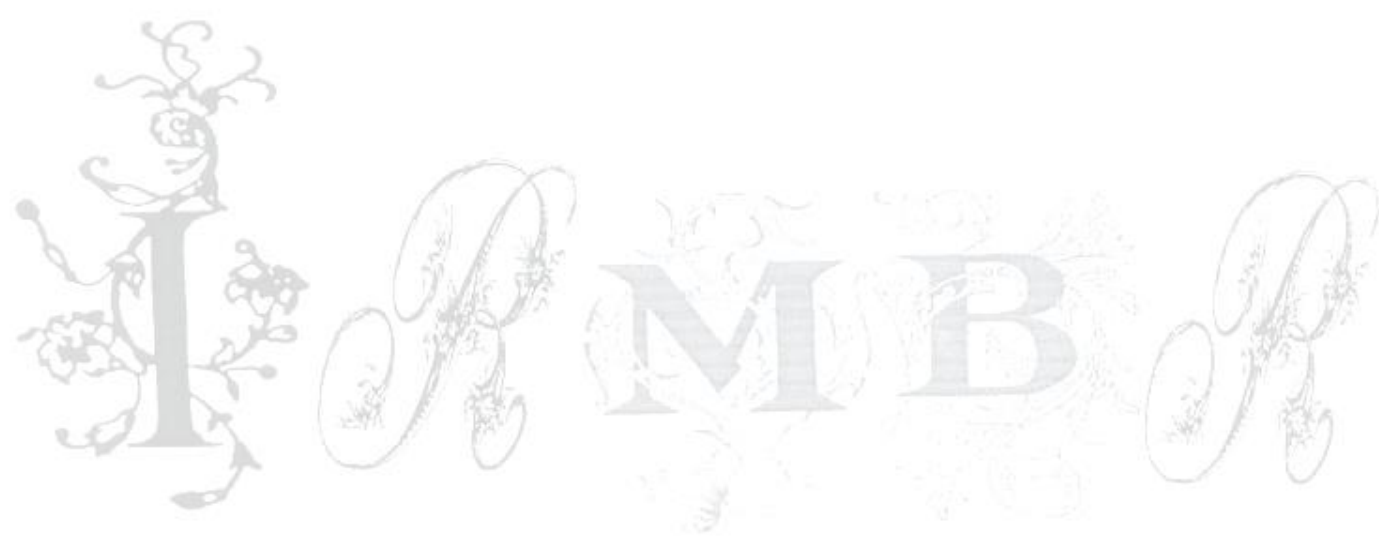

